\title{
ANTIOCHIA I ALEKSANDRIA - CZY ZAWSZE TEOLOGICZNA POLARYZACJA? Problem transcendencji oraz immanencji Boga w teologii Cyryla Aleksandryjskiego i Jana Złotoustego
}

\author{
,[...] Deus non est notus nobis in sui natura, \\ sed innotescit nobis ex operationibus vel effectibus eius"1. \\ „Ci, którzy się dopasowali do Boga i osiagnęli [...] przebóstwienie, \\ biorą udział nie w Bożej istocie, a w Boskiej energii"².
}

Teologia szkoły aleksandryjskiej i antiocheńskiej stała się symbolem pozostającej w konflikcie teologicznej polaryzacji. Jednoczone soborowymi, dogmatycznymi sformułowaniami te dwa typy myślenia o Bogu wciąż pozostawały przeciwległymi punktami widzenia. Dotyczyło to zarówno metody i sposobu interpretacji Pisma Świętego, jak również głównych kwestii dogmatycznych na płaszczyźnie teologii trynitarnej i chrystologii. Chodzi tu przede wszystkim o rozumienie współzależności pomiędzy jednością a troistością Trójcy Świętej, jak również o ciągnące się wiekami chrystologiczne dyskusje, które często naznaczone były brutalną i daleką od pokojowej teologiczną i personalną konfrontacją. Przeciwne sobie partie w teologicznych dyskusjach odnajdywały wspólny mianownik jedynie w błogosławionej antynomii, którą tysiąc lat później św. Grzegorz Palamas (1296-1359) nazwie „kryterium pobożności”’3. Jaskrawym przykładem takiego antynomicznego związku dwóch

${ }^{*}$ Dr Viktor Zhukovskyy - kierownik Katedry Teologii na Wydziale Filozoficzno-Teologicznym Ukraińskiego Katolickiego Uniwersytetu we Lwowie; e-mail: viktor@ucu.ua.

${ }^{1}$ Thomas de Aquino, Summa theologica I 13, 8 (conclusio).

${ }^{2}$ Gregorius Palamas, Capita CL: physica, theologica, moralia et practica 150, PG 150, 1225B. Jeśli nie zaznaczono inaczej, przekładu tekstów oryginalnych w niniejszym artykule dokonał Autor; teksty biblijne są cytowane za Biblią Tysiąclecia.

${ }^{3}$ Por. Gregorius Palamas, Theophanes, PG 150, 932D: „Musimy potwierdzić dwie rzeczy jednocześnie i zachować ich autonomię, jako kryterium pobożności [...]. To właściwa rzecz, aby na początku potwierdzić jedną rzecz, a wtedy inną, o ile oba twierdzenia są prawdziwe"; tenże, Capita 120-123, PG 150, 1205AD; zob. P. Evdokimov, Eschatological Transcendence, w: Orthodoxy: Life and Freedom, Essays in honour of Archbishop Iakovos, ed. A.J. Philippou, Oxford 1973, 40. 
odrębnych teologicznych paradygmatów jest formuła chalcedońska oraz doktryna trynitarna. Obok zasadniczych dogmatycznych sformułowań, wyrażających optymalny teologiczny consensus, istniała jeszcze jedna kluczowa kwestia, która wciąż wymagała i nadal wymaga antynomicznego rozstrzygnięcia. Tym zagadnieniem jest mianowicie współzależność pomiędzy transcendencją a immanencją Bożej natury w stosunku do rzeczywistości stworzonej.

Zrozumienie ontologicznego problemu współzależności pomiędzy transcendentnym a immanentnym Bogiem, a także jego pojęciowo-konceptualne wyrażenie pełni pierwszoplanową soteriologiczną rolę ze względu na konieczność uzasadnienia możliwości poznania Boga, udziału człowieka w Bożej naturze i jego przebóstwienia. Ontologiczny dystans między tym, co boskie i tym co ludzkie, zanika właśnie dzięki Wcieleniu Syna Bożego, który w jednej Bożej Osobie zjednoczył dwa przeciwne światy: niestworzony i stworzony, wieczny i doczesny, nieskończony i ograniczony, boski i ludzki. Temat współzależności Wcielenia i Przebóstwienia jest jednym z głównych w myśli Ojców Kościoła już od czasów Ireneusza z Lyonu (ok. 140-202) ${ }^{4}$. Jednakże problem teologicznej interpretacji oraz dogmatycznego wyrażenia Dobrej Nowiny o złączeniu jedynego Bożego życia z różnorodnością rzeczywistości świata, wciąż pozostaje aktualny. Napięcie między absolutną „innością" istnienia wewnątrz Trójcy (Bóg in se, theologia) a jednocześnie ontologiczną „bliskością” Boga w Jego Objawieniu i opatrznościową obecnością w świecie (Bóg ad extra, oikonomia) poprzez łaskę, moc, energię - stanowiło i nadal stanowi najważniejszy punkt teologicznej myśli. Od niej rozpoczynają swe rozważania o teologii XX wieku Stanley J. Grenz i Roger E. Olson: „W swych najlepszych momentach teologia chrześcijańska zawsze starała się znaleźć równowagę między dwiema powiązanymi ze sobą biblijnymi prawdami - Bożą transcendencją i Bożą immanencją. Z jednej strony Bóg jest transcendentny względem świata. Jest samowystarczalny i istnieje niezależnie od świata. Panuje nad wszechświatem i przychodzi do naszego świata z zewnątrz [...]. Z drugiej zaś strony jest immanentny wobec świata. To znaczy, iż jest On zawsze obecny w swym stworzeniu. Bóg bierze najbardziej skuteczny udział we wszystkim, co odbywa się we wszechświecie w i historii ludzkości [...]. Teologowie każdej epoki stykali się z koniecznością znalezienia takiego sformułowania, dotyczącego chrześcijańskiej wizji natury Boga, które by równoważyło, konfirmowało, a zarazem trzymało w twórczym napięciu Boską transcendencję oraz immanencję"s.

${ }^{4} \mathrm{O}$ podejściu Ojców Kościoła do zagadnienia przebóstwienia człowieka i jego związku z Wcieleniem Syna Bożego, por. N. Russell, The Doctrine of Deification in the Greek Patristic Tradition, Oxford 2006.

${ }^{5}$ С. Гренц - Р. Олсон, Богословие $і$ богословы XX века, перев. О. Розенберг, Колоквиум 2011, 9 . 
Kwestia ta była jedną z najistotniejszych także w IV i V wieku, dlatego też wydaje się, że interesująca może być analiza myśli teologicznej, terminologii oraz konceptualnego ujęcia objawionej prawdy o Bożej transcendencji i immanencji przez dwóch przedstawicieli przeciwnych sobie teologicznych szkół: antiocheńskiej i aleksandryjskiej, to znaczy Cyryla Aleksandryjskiego (ok. 378-444) i Jana Złotoustego (ok. 350-407).

1. Cyryl Aleksandryjski o istnieniu i działaniu Boga. Zagadnienie transcendencji i immanencji Boga w stosunku do stworzenia Cyryl rozpatruje w trynitarno-chrystologicznym kluczu, głównie w czterech swych pracach: Skarbiec nauk o świętej $i$ wspótistotnej Trójcy (Thesaurus de sancta et consubstantiali Trinitate), O świętej $i$ wspótistotej Trójcy (De sancta et consubstantiali Trinitate dialogi), O jedności osoby Chrystusa (Quod unus sit Christus) oraz $O$ Wcieleniu Jednorodzonego (De incarnatione Unigeniti). W nich odnajdujemy listę czytelnych i jednoznacznych tekstów, w których biskup Aleksandrii dokonuje rozróżnienia między Bogiem w Jego „,wewnętrznym” i ,zewnętrznym” istnieniu. Leonidas C. Contos w tym miejscu zauważa, iż Cyryl „,nalega, by w sytuacji zaprzeczenia prawdziwemu rozróżnieniu pomiędzy istotą i energiami Boga, tzn. między atrybutami zrodzenia i stworzenia, porządek stworzony rozpatrywać jako całkowicie nieodłączny od niestworzonego; trzeba wówczas stworzeniami nazwać Syna i Ducha Świętego, co oznacza jednocześnie zrodzenie i stworzenie przez Boga; cała natura w tym wypadku jest przebóstwiona"'.

Ojciec Jerzy W. Florowski podkreśla również, że Cyryl Aleksandryjski rozróżnia w Bogu „istnienie” od „działania”. Nie ma takiego miejsca w świecie widzialnym czy też niewidzialnym, gdzie Boska energia byłaby nieobecna, nieruchoma, czy w ogóle taka, że stopniowo się zmniejsza i słabnie. Dla Cyryla ta sakramentalna „energiczna” obecność Boskiego Logosu odnosi się do każdego czasu i do wieczności, do wszelkiej przestrzeni i sięga poza wszelkie wyobrażalne wymiary istnienia. W swoim piśmie Krótkie uwagi o Wcieleniu Jednorodzonego (Scholia de Incarnatione Unigeniti) potwierdza on antynomiczną realność Boskiej natury, akcentując przy tym z jednej strony, że „Bóstwo przekracza jakiekolwiek miejsce, granice czy dającą się zmierzyć wielkość, ponieważ nic go nie może ogarnaćc", a z drugiej zaś podkreślając,

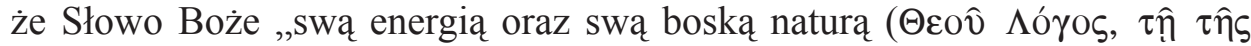

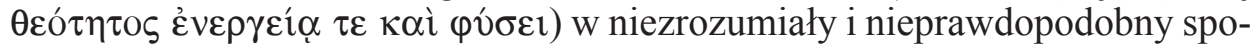
sób napełnia wszystko, zamieszkuje we wszystkim"7. Antynomia Bożej natury według Cyryla polega też na tym, że Bóg jest zarazem Jedyny i Prosty

${ }^{6}$ L.C. Contos, The Essence-Energies Structure of Saint Gregory Palamas with a Brief Examination of its Patristic Foundation, GOT 12 (1967) 286.

${ }^{7}$ Cyrillus Alexandrinus, De incarnatione Unigeniti 693, 1-10, ed. G.M. de Durand, SCh 97, Paris 1964, 234. 
w swej istocie, a różnorodny co do działania swoich energii. To wykracza poza wszelką konceptualizację czy możliwość zrozumienia ${ }^{8}$.

Przeprowadzając wyraźną linię rozróżnienia „,wewnętrznego” bycia Boga od „zewnętrznej” obecności w stworzeniu, Cyryl jest zdecydowanie zależny od teologicznej myśli swego poprzednika, Atanazego Aleksandryjskiego (ok. 295-373). Odrzucając jednakże pojęcia „wola” oraz „refleksja” Cyryl posiłkuje się w swej myśli teologicznej zwrotem „boska energia" "w kontekście działania Boga w świecie. Stwierdza, że „stwarzanie jest zadaniem energii ( $\varepsilon v \varepsilon \rho-$

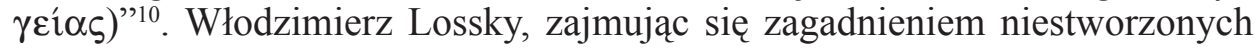
boskich energii, powołuje się na te same słowa Cyryla Aleksandryjskiego, które wykorzystywał swego czasu w swojej argumentacji Grzegorz Palamas:

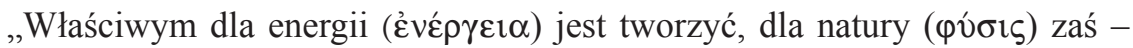
bycie źródłem stworzenia""11.

W Skarbcu nauk o świętej i wspótistotnej Trójcy (Thesaurus de sancta et consubstantiali Trinitate) i w traktacie $O$ świętej $i$ wspótistotej Trójcy (De sanc-

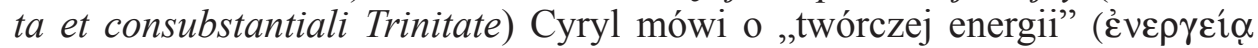
$\delta \eta \mu$ เо $\left.\rho \gamma_{1 \kappa} \hat{n}\right)^{12}$, dzięki której Bóg stworzył człowieka i cały wszechświat:

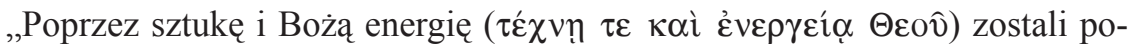
wołani do istnienia aniołowie i ludzie, niebo i ziemia, wół i koń, drzewo i kamień"13.

Cyryl w arystotelesowski sposób w tym samym działaniu Boga wyróżnia

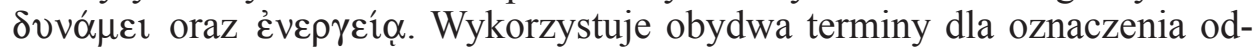
wiecznego i twórczego działania Boga-Ojca.

„Oto wszystko, co powstaje, naprawdę posiada jako swoje źródło Ojca

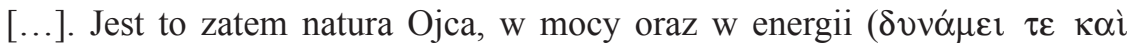

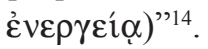

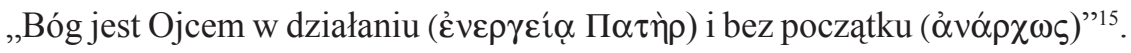

${ }^{8}$ Por. tenże, De sancta et consubstantiali Trinitate dialogi II 442, 43-44, ed. G.M. de Durand, SCh 231, Paris 1976, 298.

${ }^{9}$ Podobieństwa można odnaleźć w dziełach Atanazego: Orationes adversus Arianos (PG 26, 12-525A) i Oratio de incarnatione Verbi (PG 25, 95A-197A, lub ed. Ch. Kannengiesser, SCh 199, Paris 1973); por. G. Florovsky, The Concept of Creation in St. Athanasius, StPatr 6 (1962) 55.

${ }^{10}$ Cyrillus Alexandrinus, Thesaurus de sancta et consubstantiali Trinitate 18, PG 75, 312CD. 313A; por. Contos, The Essence-Energies Structure, s. 286.

${ }^{11}$ Gregorius Palamas, Capita 143, PG 150, 1220D; por. В. Лосский, Очерк мистического богословия Восточной Церкви, перев. В.А. Рещиковой, Москва 1991, 58.

${ }^{12}$ Cyrillus Alexandrinus, De sancta et consubstantiali Trinitate dialogi II 437, 4, SCh 231, 282.

${ }^{13}$ Tamże II 441, 27-29, SCh 231, 294.

${ }^{14}$ Tamże II 458, 1-3, SCh 231, 344.

15 Tamże II 458, 23, SCh 231, 344. W innym miejscu Cyryl (tamże V 580, 25, ed. G.M. de 
Cyryl akcentuje przy tym, iż energia Ojca posiada boską naturę oraz boskie pochodzenie:

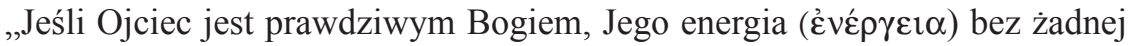
wątpliwości będzie wówczas tak samo Boska $(\theta \varepsilon i ́ \alpha)$ "16.

Wyraźnie rozróżniając między istotą Trójcy Przenajświętszej a Jej ekonomiczną działalnością, aleksandryjski teolog zauważa:

„Działanie niestworzonej istoty stanowi coś wspólnego, choć jest charakterystyczne i dla każdej osoby z osobna, wobec czego za trójhipostatyczne działanie odpowiada każda z nich, co przemawia z kolei za doskonałością osoby. Zatem działa Ojciec, ale przez Syna w Duchu. Syn działa także, ale jako siła Ojca, o ile Syn czerpie od Niego i w Nim, według własnej hipostazy. I Duch działa również, bo jest Duchem Ojca i Syna, Duchem wszechmogącym, Duchem mocy"17.

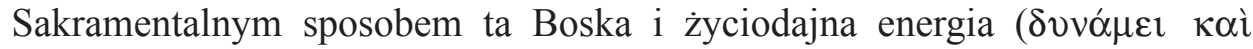

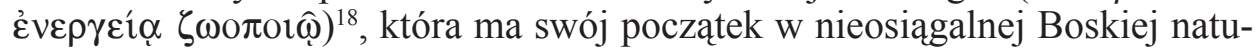
rze Ojca, wypełnia wszystkie wymiary stworzonego wszechświata. W innym miejscu z kolei Cyryl zaznacza:

„Bóg istnieje we wszystkich rodzajach bytu i w każdym na sposób szczegól-

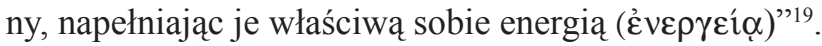

Mówiąc o rozdziale hipostaz Trójcy w Trójjedynym Bogu, uwydatnia zarazem

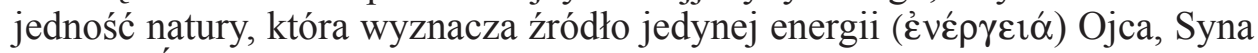
i Ducha Świętego ${ }^{20}$. Przypominając fragment o darze języków z wydarzenia Pięćdziesiątnicy (Dz 2, 5-11), Cyryl podkreśla, że to także jest efekt energii

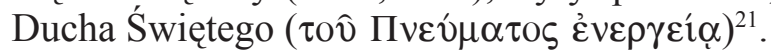

Obok tych przemyśleń biskup Aleksandrii w swych chrystologicznych pra-

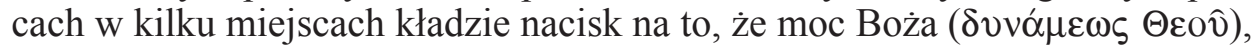
która przede wszystkim pochodzi od Ojca, jest tą samą moca, którą posiada Wcielony Bóg. Jest ona także energią Boga-Ojca, poprzez którą wzbudził On z martwych Jezusa Chrystusa i posadził po swej prawicy ${ }^{22}$. Cyryl poświęca życiodajnemu działaniu Boskiej energii więcej uwagi przy okazji rozważań o na-

Durand, SCh 237, Paris 1977, 368) mówi o „naturze, władzy i energii Boga” (

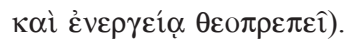

${ }^{16}$ Tamże III 468, 45-46, SCh 237, 28.

17 Tamże VI 618, 34 - 619, 2, ed. G.M. de Durand, SCh 246, Paris 1978, 104; por. Лосский, Очерк мистического богословия, s. 64.

${ }^{18}$ Cyrillus Alexandrinus, De sancta et consubstantiali Trinitate dialogi VI 601, 27, SCh 246, 54.

${ }^{19}$ Tamże V 570, 7-8, SCh 237, 336.

${ }^{20}$ Tamże VII 642, 26-32, SCh 246, 174.

${ }^{21}$ Tamże VII 659, 16-17, SCh 246, 224.

${ }^{22}$ Por. tenże, Quod unus sit Christus 767d, 25-35, SCh 97, 478. 
turze ciała Jezusa Chrystusa. Analizuje Wcielenie Boskiego Logosu, w którym Jezus Chrystus, w niedający się opisać sposób, jest przepełniony boską

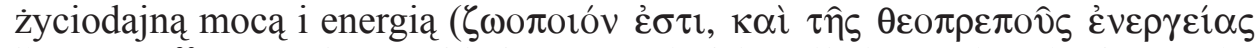

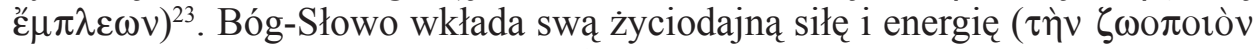

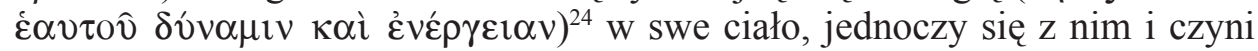
swoim. Cyryl docenia zatem ze wszech miar odnawiające i życiodajne działanie Bożej energii i mocy jako takiej, dzięki której Boski Logos się objawia.

Aleksandryjski biskup, a tysiąc lat po nim Grzegorz Palamas, posługuje się pojęciem ,przypadłości/akcydensu” w stosunku do Boga, aby opisać związek między Boskimi atrybutami i Jego istotą ${ }^{25}$. Gregorios Akindynos (ok. 1300-1349), komentując to, zaznaczył, iż Cyryl rozwija tę myśl w kontekście polemicznym ${ }^{26}$. Theodor Damian, odnosząc się do Cyrylowego sposobu wypowiedzi na temat energii jako przypadłości (akcydensu), stwierdza, że biskup posługuje się wspomnianym określeniem bardzo ostrożnie; nie odwołuje się do znaczenia filozoficznego tego terminu, ale stosuje je wyłącznie ze względu na brak właściwszego pojęcia, którym można byłoby opisać „,energiczny” wymiar Boskiego istnienia ${ }^{27}$. „Aby zaakcentować odwieczność i niestworzoność energii, w sposób szczególny stwierdza, iż są one podobne do przypadłości (akcydensu), albo że są one jak przypadłość (akcydens). Właśnie dlatego energie należą do Boskiego bytowania i nie wnoszą do niego niczego nowego, obcego, przypadłościowego (akcydentalnego) sensu stricto, czy też sztucznego"28.

2. Jan Zlotousty o niepoznawalności i poznawalności Boga. Zagadnienie ontologicznej ,przerwy” między Boską transcendencją i immanencją wobec świata i człowieka, stanowi centralny temat dogmatycznych rozważań, jakie rozwija Jan Chryzostom. Zasadniczy ich punkt sprowadza się do jednoznacznego rozróżnienia pomiędzy niemożnością poznania istoty Boga a poznawczą świadomością Jego istnienia. Znaczącym dziełem Chryzostoma, w którym porusza tę kwestię, są skierowane przeciw anomejczykom Homilie o niepojętości Boga (Homiliae de incomprehensibili Dei natura contra Anomoeos). Genezy tego traktatu należy szukać w kontekście polemiki z anomejczykami i eunomianami, będącymi skrajnym odłamem arian, który głosił, iż Chrystus jest całkowicie niepodobny do Boga-Ojca. Oprócz tego anomejczycy forsowali tezę o możliwości bezpośredniego i całkowitego poznania Boga w Jego

${ }^{23}$ Tamże 723, 10-11, SCh 97, 330.

${ }^{24}$ Tamże 777, 29-37, SCh 97, 510.

${ }^{25}$ Por. T. Damian, A Few Considerations of the Uncreated Energies in St. Gregory Palamas ' Theology and His Continuity with the Patristic Tradition, „The Patristic and Byzantine Review” 15 (1996-1997) 104.

26 Por. J.S. Nadal, La critique par Akindynos de l'herméneutique patristique de Palamas, „Istina” 19 (1974) 305 i 321-322.

${ }^{27}$ Por. Damian, A Few Considerations, s. 107.

${ }^{28}$ Tamże. 
istocie. W tej konfrontacji Jan Chryzostom jawi się jako następca i kontynuator Ojców Kapadockich, a w szczególności Grzegorza z Nyssy (ok. 335-395), po którym odziedziczył apofatyczny styl teologizowania ${ }^{29}$.

Św. Jan Chryzostom w swych rozważaniach, dotyczących niemożności poznania Boga w punkcie wyjścia, opiera się na tych samych podstawach, co i Ojcowie Kapadoccy, a mianowicie na doktrynie trynitarnej oraz polemice ze wspomnianą wyżej herezją Aecjusza (IV wiek) ${ }^{30}$. Wykorzystując paralelę Boskiego istnienia oraz nieba, Złotousty krytykuje anomejczyków za to, iż nadają imię istocie Boga. Tymczasem, jego zdaniem, akcent należy położyć na niemożność przeniknięcia istoty Boga, na absolutną jej niepoznawalność i bezimienność:

„Jeżeli sama istota [Boga] jest nieznana nie przez to, że istnieje, a przez to, jaka ona jest, wobec tego jej nazywanie byłoby skrajnym szaleństwem. Nawet jeśli byłaby ona poznawalna i znana, to i tak niebezpiecznym dla nas byłoby nazywanie istnienia Boga [...]. Jakiego przebaczenia, czy też jakiego usprawiedliwienia potrzebują ci, którzy ośmielają się czynić tak [to znaczy nadawać imiona] w relacji do istoty Boga? Jeżeli sama istota [Boga] jest nieznana, to konieczne jest odstapienie od tych [którzy temu się sprzeciwiaja], jako od tych, którzy są niespełna rozumu [...]. Nie zdając sobie sprawy z samej istoty, jak oni [anomejczycy] mogliby nazywać ją po imieniu?"31.

W innym miejscu Jan Chryzostom kontynuuje:

„Ta bezmyślność jest tak oczywista i przewinienie tak wielkie, że nawet odsunięci od prawdy poganie, nigdy nie ośmielili się twierdzić coś podobnego. Nikt z ich grona nigdy nie odważył się wskazywać na istotę Boga i określać ją jedną nazwą [...]. [Tymczasem] oni [heretycy, czyli wyznawcy Aecjusza i Eunomiusza] twierdzą, że my nie znamy tego, kogo wyznajemy? W ogóle na to nie trzeba by odpowiadać, skoro już Pismo uzasadnia, że niemożliwe

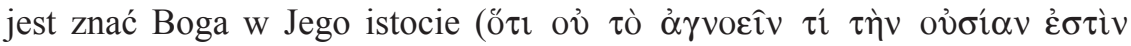
ó @eós); [...] nie znają Boga nie ci, którzy nie znają Jego istoty, ale ci, którzy starają się poznać Jego istotę [...]. Od nas wymaga się jedynie wiedzy o tym, że Bóg istnieje, a nie badanie Jego istoty" ${ }^{32}$.

Na zarzut anomejczyków:,Wówczas wy oddajecie pokłon temu, kogo nie znacie" "33, Złotousty odpowiada także w Homilii do Psalmu 138 (Homilia

${ }^{29}$ Por. И. Мейендорф, Введение в святоотеческое богословие, Киев 2002, 205.

${ }^{30}$ Szerzej o herezji anomejczyków por. В. Карташев, Вселенские Соборы, Москва 1994, 81-82.

${ }^{31}$ Joannes Chrysostomus, De incomprehensibili Dei natura contra Anomoeos V 4, PG 48, 742 , lub ed. A.M. Malingrey, SCh 28bis, Paris 1970, 300, w. 335-355, tłum. za: Иоанн Златоуст, Полное собрание творений в 12 томах, vol. I/2, Москва 1991, 541.

32 Tamże V 5, PG 48, 742 lub SCh SCh 28bis, 302-304, w. 367-384.

${ }^{33}$ Ariusz (ok. 256-336), wychodząc ze swojego rozumienia prostoty Boga-Ojca jako absolutnej 
in Psalmum 138), w której dokładnie oddziela to, „co powiedziano o istocie Boga” od tego, co stanowi „boskie właściwości”.

„On [prorok Dawid] wie, iż Bóg jest zadziwiający, wielki i potężny, ale to, kim jest w swej istocie, $[\ldots]$ jaka jest Jego wielkość i w jaki sposób Mu wszystko jest poddane, tego nie wiemy. Pomimo tego jednak, taka nieznajomość jest dowodem wiedzy, choć dziwne są moje słowa [...]. W ten oto sposób mamy do czynienia z Objawieniem wiedzy, którą ujawnia nam nieznajomość, bo bywa taka nieznajomość, która świadczy o wiedzy"34.

Jan Chryzostom głosił, iż istota Boga jest niewątpliwie niepoznawalna i niedostępna dla człowieka, stąd teologia apofatyczna Złotoustego składa się z szerokiego spektrum terminów, którymi opisuje Boga: niewypowiedziany

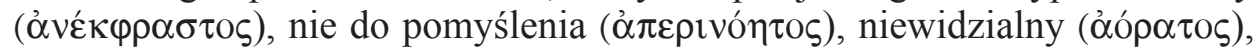

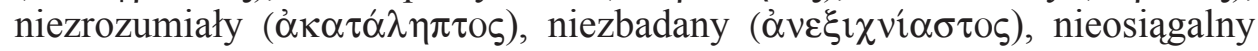

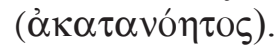

„Zawołajmy do niewypowiedzianego, niezrozumiałego, niewidzialnego, niedostępnego Boga, który przezwycięża siłę ludzkiego języka, który przewyższa rozumienie śmiertelnego rozumu, niezbadanego przez aniołów, niewidzialnego dla serafinów, nieosiagalnego dla cherubinów, niewidzialnego dla zwierzchności, mocy, potęg, i w ogóle dla jakiegokolwiek stworzenia, a poznawalnego jedynie dla Syna i Ducha Świętego"35.

Bóg zatem w swoim wewnątrz-trynitarnym życiu jest niedostępny nie tylko dla ludzi, ale także dla całego stworzonego istnienia, widzialnego i niewidzialnego. Takie ograniczenie w poznaniu Boga odnosi się również do aniołów i do tych bytów niebiańskich, które przebywają najbliżej Boga. One bowiem również nie mogą Boga ani zgłębić, ani na Niego spoglądać.

„Czy to dziwne - zapytuje Złotousty - że one [byty niebiańskie] nie mają dokładnej wiedzy o istocie [Boga]? To nie jest ani trochę trudne do udowodnienia; o jak licznej bowiem ilości dzieł Boskiej ekonomii byty niebiańskie nie wiedzą - ani moce, ani zwierzchności, ani potęgi”36.

monady, doszedł ostatecznie do agnostycyzmu, zaprzeczając nawet możliwość poznania Ojca przez Syna. Eunomiusz (zm. 392) z kolei głosił gnozeologiczny optymizm.

${ }^{34}$ Joannes Chrysostomus, Expositio in Ps. 138, 4, PG 55, 416, thum. za: Иоанн Златоуст, Беседы на Псалмы, Москва 2003, 522.

${ }^{35}$ Joannes Chrysostomus, De incomprehensibili Dei natura contra Anomoeos III 1, PG 48, 720, lub SCh 28bis, 190, w. 52-59. Jak podkreśla A.M. Malingrey w swym komentarzu (SCh 28bis, 191,

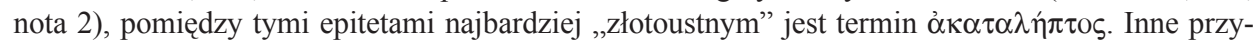

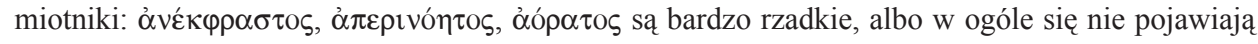
w dziełach Jana.

${ }^{36}$ Tamże IV 2, PG 48, 729, lub SCh 28bis, 238, w. 112-116. A.M. Malingrey (SCh 28bis, 238,

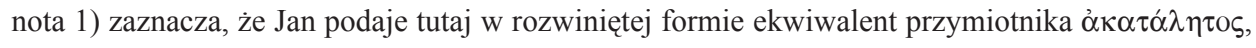


Mówiąc o poznaniu Boga, Jan Chryzostom często odwołuje się do nauki Pawła Apostoła, który

„rozmyślając o wiedzy $[\ldots]$ nie twierdzi «ja nie znam Boga», ale «ja nie mam o Nim doskonałego i jasnego zrozumienia» [...]. To, że On [Bóg] jest - my wiemy, ale tego kim On jest w swej istocie - nie wiemy: [...] kto przystępuje do Boga musi wierzyć, że On istnieje (Hbr 11,6). On nie wyjawił, kim jest $\mathrm{w}$ istocie, dlatego nikt tego nie wie. O tym natomiast, że Bóg jest miłującym człowieka, że jest miłosierny - my wiemy, ale do jakich granic - nie wiemy" ${ }^{37}$.

Komentując fragment Pawłowego Listu do Koryntian, w którym autor rozważa kwestię poznania Boga, Złotousty stawia pytanie:

„Co mówi Paweł w słowach: «Po części tylko Boga poznajemy» (1Kor 13,

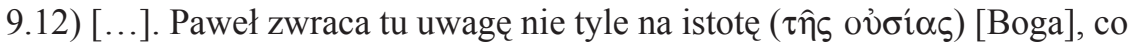

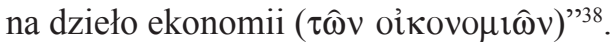

Nawiązując do Pawłowego określenia „częściowo” Złotousty zaznacza, iż Apostoł powiedział „Po części [...] poznajemy” nie w tym znaczeniu, że jakaś

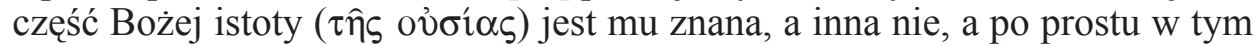
znaczeniu, iż wie, że Bóg istnieje, ale nie wie tego, Kim jest Bóg w swej isto$\mathrm{cie}^{39}$. W innym miejscu tego samego dzieła Jan, kategorycznie odrzucając wszelkie próby poznania Bożej natury, pyta:

„Co niegdyś pragnęli poznać ci, którym Paweł [...] zamknął usta? [...]. Oni

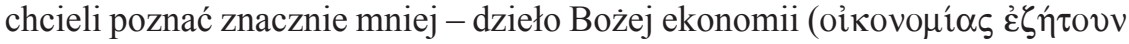

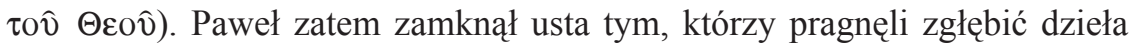
Bożej ekonomii. On im nie pozwolił nawet na to, a ty, który badasz błogosławioną $[\ldots]$ naturę nie uważasz siebie za godnego [uderzenia] tysiąca piorunów? Czyż nie jest to skrajna głupota?"40.

Złotousty wciąż tworzy swą teologię na zasadzie antynomii, gdy z jednej strony akcentuje wszechobecność Boga, a z drugiej - podkreśla niemożność odkrycia tajemnicy Jego istoty.

„Ty wszystko napełniasz, wszędzie jesteś obecny, nie po części, a [...] w pełni [...]. On [Bóg] przewyższa moje rozumienie, pokonuje mój rozum. Także promienia słonecznego nie jesteśmy w stanie przeniknąć i dogłębnie

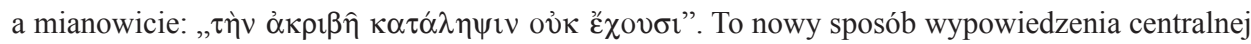
myśli homilii, podkreślający: „niemożność uzyskania wiedzy na temat istoty Boga”.

37 Joannes Chrysostomus, Expositio in Ps. 138, 2, PG 55, 413, thum. za: Иоанн Златоуст, Беседы на Псалмы, s. 518.

38 Joannes Chrysostomus, De incomprehensibili Dei natura contra Anomoeos I 5, PG 408, 706, lub SCh 28bis, 124, w. 279-283.

${ }^{39}$ Tamże I 5, PG 48, 706, lub SCh 28bis, 126, w. 291-301.

${ }^{40}$ Tamże II 5, PG 48, 715, SCh 28bis, 170-172, w. 357-373. 
uchwycić jego sensu, a jednocześnie nas to zadziwia. Dokładnie tak samo jest w przypadku poznania Boga. Nie posiadamy doskonałej wiedzy o Nim.

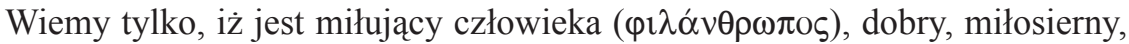
wyrozumiały i wszechobecny, ale jaki jest $w$ istocie lub w jakiej mierze wspomniane cechy są dla Niego charakterystyczne, albo w jaki sposób wszędzie przebywa, tego nie wiemy"41.

„Bóg nie tylko jest wszędzie obecny, ale i kieruje wszystkim, ochrania i strzeże $[\ldots]$ i czyni to w nadnaturalny sposób" ${ }^{\prime 42}$.

Prezentując swoje rozumienie działania Boskiej natury Jan Chryzostom zadaje pytanie o proces stwarzania, ale od razu odrzuca jakąkolwiek próbę odpowiedzi na nie:

„Jakże, powiedz mi, to się działo? Chcę wiedzieć, jak to było? Albo nie, ja nie chcę wiedzieć, jak to było, dlatego że jest to niemożliwe; ale wierzę w wydarzenia i adoruję ich Sprawcę"43.

Najważniejsze w antynomicznym myśleniu o Bogu jest wyważone podejście, ponieważ stwierdzenie niepoznawalności istoty rodzi konieczność stworzenia odpowiedniego aparatu pojęciowego, aby możliwie najbardziej adekwatnie oddać immanentny ,,aspekt” Bożej natury - Jego obecność w świecie.

W dokonanej przez Jana Chryzostoma konkretyzacji Bożej „dwuwymiarowości" zauważa się dychotomiczne podejście - oto wciąż podkreśla on absolutną niedostępność i nieosiągalność istoty Boga, ale równocześnie podaje „środki”, które ze względu na „wielkoduszność, łaskę i miłosierdzie” Boga mogą stać się sakramentalnym źródłem Jego poznania. Manifestując swą dobroć Bóg odkrywa swą naturę wobec człowieka na tyle, na ile jest on w stanie ją pojąć $c^{4}$.

Pełna obecność Boga w świecie oraz przenikanie przez Niego wszystkich wymiarów świata stworzonego są w refleksji teologicznej Jana Złotoustego

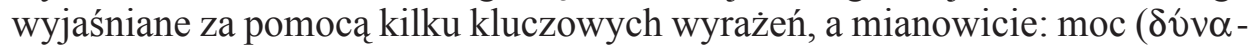

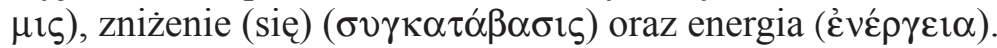

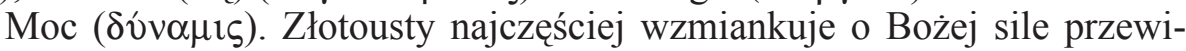
dywalności, sile myślenia i sile twórczej, za pomocą której Bóg nie tylko stworzył:

${ }^{41}$ Joannes Chrysostomus, Expositio in Ps. 138, 2, PG 55, 413-414, tłum. za: Иоанн Златоуст, Беседы на Псалмы, s. 519.

${ }^{42}$ Tamże 138, 3, PG 55, 414, (138, 3), thum. za: Иоанн Златоуст, Беседы на Псалмы, s. 519.

${ }^{43}$ Tamże 138, 3, PG 55, 415, thum. za: Иоанн Златоуст, Беседы на Псалмы, s. 520.

${ }^{44}$ G. Florowski (St. Gregory Palamas and the Tradition of the Fathers, online: http://www. myriobiblos.gr/texts/english/florovski_palamas.html [sprawdzono: 20.08.2013]), zwracając uwage na apofatyczne podejście Złotoustego co do istoty Boga i możliwości przebóstwienia człowieka, stawia pytanie: ,jeśli Bóg jest absolutnie «nieosiagalny» w swej istocie, co jest jednoznaczne z tym, iż Jego natura nie może być tak zwyczajnie «objawiona», to jak w ogóle można mówić o «theosis»?". 
„,nas nieistniejących, ale i zachowuje stworzonych”45, „ponieważ nie tylko dla otrzymania daru istnienia, ale i dla jego zachowywania i kontynuowania, potrzebujemy Jego siły”46. „Bóg posługuje się swą Boską siłą na korzyść ludzi”47.

Zniżenie (się) ( $\sigma v \gamma \kappa \alpha \tau \alpha ́ \beta \alpha \sigma \iota \varsigma)$. Wyrażenie boskiego „zniżenia (się)” jest potrzebne Chryzostomowi, aby wyjaśnić nieosiagalność Bożej istoty zarówno przez człowieka, jak i przez wszystkie „siły wysokości”. Oddala się tym samym od słów proroka Izajasza, aby jeszcze bardziej zaakcentować bliskość Boga wobec świata, Jego immanencję. U Izajasza czytamy:

„W roku śmierci króla Ozjasza ujrzałem Pana, siedzącego na wysokim i wyniosłym tronie, a tren Jego szaty wypełniał świątynię. Serafiny stały ponad Nim; każdy z nich miał po sześć skrzydeł; dwoma zakrywał swą twarz, dwoma okrywał swoje nogi, a dwoma latał. I wołał jeden do drugiego: «Święty, Święty, Święty jest Pan Zastępów. Cała ziemia pełna jest Jego chwały»" (Iz $6,1-3)$.

Jan Chryzostom, wyjaśniając zwrot „ujrzeć Pana” (Iz 6, 1), konstatuje:

„Powiedz mi, dlaczego one zakrywają twarze i odgradzają się skrzydłami? Jaka inna może być tego przyczyna, jeśli nie to, iż nie mogą po prostu znieść blasku promieni pochodzących od tronu? Dodatkowo jeszcze serafiny nie

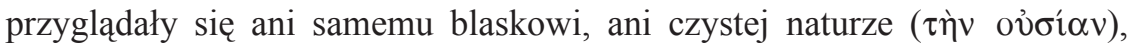
a dostrzegały ledwie zniżenie ( $\sigma v \gamma \kappa \alpha \tau \alpha \dot{\beta} \alpha \sigma \iota \varsigma)$. A co to takiego zniżenie $(\sigma v \gamma \kappa \alpha \tau \alpha ́ \beta \alpha \sigma 1 \varsigma)$ ? Zachodzi ono wówczas, gdy Bóg objawia się nie takim, jakim jest w rzeczywistości, a takim, na ile ktoś słaby z powodu swej niemocy może Go oglądać. Ponadto sam prorok objaśnia własnymi słowami, czym jest owo zniżenie [...]. Z tego też powodu słysząc owo proroctwo: «ujrzałem Pana» nie myśl, że on widział samą istotę Boga, a wyłącznie zniżenie i to ciemniejsze od tego, które odbierały niebiańskie siły, ponieważ nie mógł widzieć tyle, co cherubini" ${ }^{48}$.

Aby podkreślić nieosiągalność istoty Boga, Złotousty cytuje słowa Apostoła Jana, które uwypuklają prostotę Bożej natury, której nie zniekształci objawienie się Boga w świecie. Bóg jest Prosty, ale zarazem widzialny i niewidzialny, zrozumiały i niezrozumiały. Tymczasem źródła owej prostej ,binarności” trzeba poszukiwać w dobroci i miłosierdziu Boga względem człowieka i świata. W. Lossky zwraca uwagę, iż ,Jan Złotousty owym przejawom Boga, temu wyjściu «na zewnątrz» Jego istoty nadaje psychologiczny sens: wola,

45 Joannes Chrysostomus, Expositio in Ps. 138, 1, PG 55, 412, thum. za: Иоанн Златоуст, Беседы на Псалмы, s. 517.

${ }^{46}$ Tamże 138, 2, PG 55, 413, tłum. za: Иоанн Златоуст, Беседы на Псалмы, s. 518.

${ }^{47}$ Tamże 138, 3, PG 55, 415, tłum. za: Иоанн Златоуст, Беседы на Псалмыл, s. 521.

${ }^{48}$ Joannes Chrysostomus, De incomprehensibili Dei natura contra Anomoeos III 3, PG 48, 721 722, SCh 28bis, 200, w. 157-171. 
będąca miłosierną, schodzi do wyższego rzędu stworzeń" ${ }^{49}$. Interpretując słowa Apostoła Jana, zgodnie z którymi „Boga nikt nigdy nie widział” (J 1, 18) w kontekście wielu biblijnych przeciwnych tej myśli passusów (Iz 6, 1; Dn 7, 9; Am 9, 1; 1Krn 22, 19), Chryzostom powtarza ideę zniżenia (się) Boga do (poziomu) proroków:

„Należy wiedzieć, że on [Jan Apostoł] mówi o pełnej wiedzy i jasnym widze-

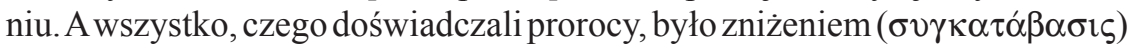

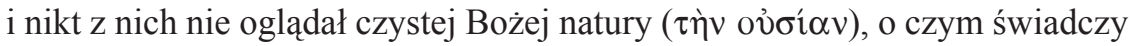
choćby to, iż owo przeżycie odbierali w różny sposób. Bóg jest prosty i niezłożony. Nie posiada obrazu. Wszyscy oni [prorocy] zaś widzieli Go pod rozlicznymi postaciami”,50.

Biskup Konstantynopola, traktując o problemie Boskiej obecności w stworzeniu, eksponuje prawdę, iż jedyny Bóg, nie rozdzielając się na rozmaite sposoby, wypełnia wielowarstwową rzeczywistość stworzonego świata: „Kropla łaski [ta część Ducha] napełniła wiedzą cały Wszechświat!"51, podkreślając tym samym, jak zauważa Grzegorz Palamas, że owa kropla łaski nierozdzielnie dzieli się, ale „Duch Święty pozostaje jedyny i niepodzielny” 52 .

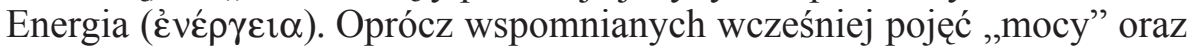
„zniżenie (się)" Jan Złotousty dla wyrażenia Bożej immanencji względem stworzonego świata, posługuje się jednakowoż terminem „energia”. Przede

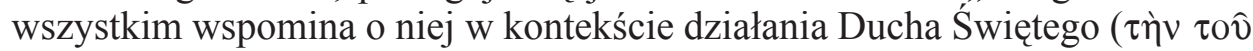

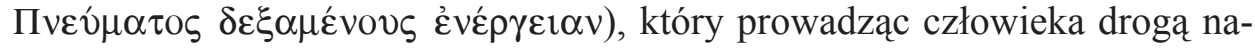
wrócenia ( $\mu \varepsilon \tau \alpha$ voí $\varsigma$ ) odnawia jego naturę ${ }^{53}$. W Komentarzu do Księgi Hioba (Commentarius in Iob) Chryzostom wyraźnie rozróżnia pomiędzy istotą Boga, będąca ponad wszelkim bytem stworzonym, a twórczymi energiami obecnymi w ogromnej różnorodności ,wielkich, niezgłębionych i niepoliczalnych dzieł Bożych”. „Patrz - zauważa Chryzostom - nigdzie nie wspomina się o istocie (

\footnotetext{
${ }^{49}$ Por. Лосский, Очерк мистического богословия, s. 65.

${ }^{50}$ Joannes Chrysostomus, De incomprehensibili Dei natura contra Anomoeos IV 179-187, SCh 28bis, 242 i 244.

${ }^{51}$ Joannes Chrysostomus, Expositio in Ps. 44, 3, PG 55, 186, tłum. za: Иоанн Златоуст, Полное собрание творений в 12 томах, vol. V/1, Москва 1995, 187.

${ }^{52}$ Por. Gregorius Palamas, Capita 74, PG 150, 1174, tłum. za: Григорий Палама, Сто пятдесят глав, Краснодар 2006, 133.

${ }^{53}$ Joannes Chrysostomus, Catecheses ad illuminandos I 15, 19-23, ed. A. Piédagnel, SCh 366, Paris 1990, 142.

${ }^{54}$ Tenże, Commentarius in Iob IX 7, 7-10, ed. H. Sorlin - L. Neyrand, SCh 346, Paris 1988, 306. Tekst opublikowany w SCh 346 i 348 jest pierwszym kompletnym wydaniem tego pisma, por. CPG 4443.
} 
energia Ducha Świętego napełniała proroków, dlatego też „wszyscy prorocy przepowiadali pod wpływem energii Ducha (

Nie zważając na absolutną niepoznawalność swojej natury, Bóg objawia siebie poprzez Boskie energie. W wielu tekstach Jana Chryzostoma obecne jest napięcie między poznawalnością i niepoznawalnością Boga. I tak, w Homiliach do Ewangelii św. Jana (Homiliae in Joannem), autor ten rozważa „dualizm” natury Boga, która z jednej strony „nie ma nic wspólnego z nami” i z „rzeczami stworzonymi”, z drugiej zaś ten sam Bóg „ukazuje się nam poprzez własne działanie". $Z$ tej też przyczyny ważne u Antiocheńczyka są dwa wymiary natury Boga: jest ona z jednej strony „daleka od nawiązywania wszelkich relacji ze stworzeniami", jest to zatem istota Boga, z drugiej zaś strony jest ona „bliska” wszystkim aspektom stworzonej rzeczywistości. Odnosząc się natomiast do Jana Ewangelisty, Złotousty podkreśla:

„natura Boga nie posiada żadnego wspólnego elementu z nami i jest daleka od tworzenia relacji ze stworzeniami, [jeśli] chodzi [...] o istotę, a nie o działanie [...]. Jest to mowa o Bogu, o którym w żadnej mierze nie można się w sposób adekwatny ani wypowiadać, ani myśleć. Dlatego Ewangelista Jan nigdzie nie posługuje się wyrazem «istota»; tak jak nie jest możliwe stwierdzenie, że Bóg

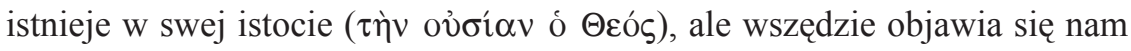

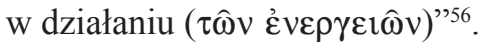

Boska energia, choć wykazuje podobieństwo do ruchu, to jednak nie stanowi żadnego rodzaju ruchu przestrzenno-materialnego, czy ruchu rozumu. Jest ona za to ściśle powiązana $\mathrm{z}$ wolą Bożą, której główny cel stanowi dobrobyt i zbawienie człowieka. Nie można w sposób definitywny i ostateczny stwierdzić, czym jest owa energia Boga, gdyż - jak dostrzega Złotousty - ludzki rozum jest za słaby i nie jest w stanie odpowiedzieć na zapytanie, na które człowiek nie może uzyskać odpowiedzi ${ }^{57}$. Ojciec Kościoła przypo-

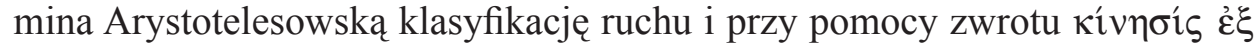

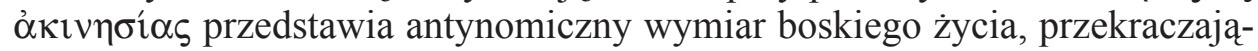
cego wszelkie opisy i wyobrażenia ${ }^{58}$.

Inny przykład antynomicznego charakteru boskiej realności odnajdujemy

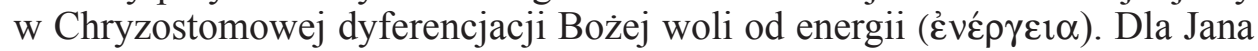
Złotoustego „wola różni się od energii jednocześnie nie będąc od niej odmien-

${ }^{55}$ Tenże, De incomprehensibili Dei natura contra Anomoeos III 3, PG 48, 721, lub SCh 28bis, 200, w. 150-151.

${ }^{56}$ Tenże, In Joannem hom. 2, 4, PG 59, 34, tłum. ang. Ph. Schaff, A Select Library of the Nicene and Post-Nicene Fathers of the Christian Church (= NPNF) ser. I, vol. 14, Grand Rapids 1889 (Reprint: Peabody 1994), 7.

${ }^{57}$ Por. G. Habra, The Patristic Sources of the Doctrine of Gregory Palamas on the Divine Energies, „Easter Christian Quarterly” 12 (1957) 341.

${ }^{58}$ Por. tamże, s. 342. 
ną"59. Boża energia to potok wszystkich dóbr pochodzących od Boga, który nigdy nie osłabia swej siły.

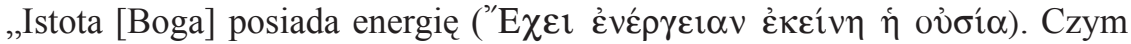

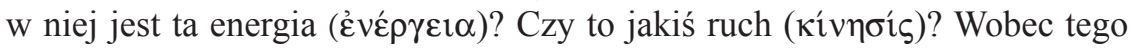
jest on niezmienny, dlatego że to, co się porusza, podlega zmianom - bezruch przechodzi w ruch" ${ }^{\circ 0}$.

Boska energia działa w nieskończoności, w niestworzoności Bożej istoty i jako skutek stoi w sprzeczności w stosunku do ludzkiego poznania ${ }^{61}$. Ograniczoność bowiem ludzkiego poznania, które tylko częściowo może przeniknąć tajemnicę Bożej natury, nie obejmuje w żadnej mierze istoty Boga. Owo poznanie dokonuje się wyłącznie na podstawie objawienia dokonanego dzięki energii, boskiej mądrości, przez którą wszechmoc Boża wszystko przenika i wszechdziała. Zrozumienie Boga jest składową ekonomii zbawienia w świecie, a wskazuje na to dość wyraźnie fakt, iż Jan Chryzostom niekiedy

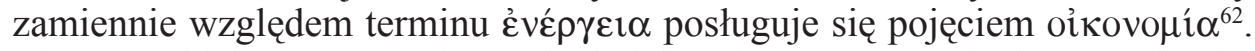
Złotousty biskup często akcentuje ludzką niemoc zrozumienia energii, aby jeszcze bardziej uwydatnić absolutną niemożność poznania istoty Boga. Dodaje przy tym, iż owa istota posiada pewnego rodzaju „pierwszeństwo przyczynowe" w stosunku do energii, nazywanej też przez naszego autora

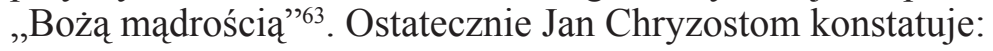

„Ewidentnym szaleństwem jest uzurpowanie sobie posiadania wiedzy o tym, kim jest Bóg w swej istocie. Aby się przekonać, iż naprawdę takie rozumowanie jest obłędem, posłużę się przykładem proroków. Prorocy, jak to już zauważyliśmy, nie tylko nie wiedzieli, kim jest Bóg w naturze, ale i nie mogli zgłębić ogromu Jego mądrości, choć to nie istota zależy od mądrości, a mądrość od istoty. Jeżeli zaś prorocy nie mogli z pewnością poznać nawet tej (Bożej cechy, tzn. mądrości), to jak błędne byłoby myślenie, że własnym osądem można określić Boską istotę?”'64.

\section{${ }^{59}$ Tamże.}

${ }^{60}$ Joannes Chrysostomus, In Epistulam ad Colossenses hom. 5, 3, PG 62, 335, tłum. ang. Ph. Schaff, NPNF ser. I, vol. 13, Grand Rapids 1889 (Reprint: Peabody 1994), 502.

${ }^{61}$ Por. Habra, The Patristic Sources, s. 343.

62 Joannes Chrysostomus, De capto Eutropio et de divitiarum vanitate hom. 9, PG 52, 403, thum. ang. W.R.W. Stephens, NPNF ser. I, vol. 9, Grand Rapids 1889 (Reprint: Grand Rapids 1956), 257; por. S.G. Papadopoulos, The Holy Trinity and the Parousia of the Holy Spirit according to St. John Chrysostom, online: http://www.myriobiblos.gr/texts/english/pap_spirit.html [sprawdzono: 21.08. 2013].

${ }^{63}$ Por. Habra, The Patristic Sources, s. 344.

${ }^{64}$ Joannes Chrysostomus, De incomprehensibili Dei natura contra Anomoeos I 188-198, SCh 28bis, 116. Jan Złotousty krytykuje w tym miejscu anomejczyków, którzy twierdzili, iż ludzki rozum jest w stanie poznać Bożą istotę. 
Podsumowując, należy podkreślić pewną dychotomię: $\mathrm{z}$ jednej strony Bóg, jedyny w swej istocie, w pełni niepoznawalny, z drugiej natomiast - niepoznawalny dla człowieka ${ }^{65}$. Jak zaznacza Stylianos G. Papadopoulos, moc Boża, Boże zniżenia i Boże energie wspólnie stanowią konstytutywny czynnik tego, co możemy się dowiedzieć o Bogu i dzięki czemu umożliwiony jest człowiekowi dostęp do Niego. Odpowiednio także różnorodne słowa, pojęcia, terminy, imiona tak często teologicznie wykorzystywane dla określenia relacji względem Boga, mają duże znaczenie nie dla ukazania istoty Boga, lecz Jego energii i ekonomii zbawienia ${ }^{66}$. Wielość Bożych imion - to efekt różnorodności Bożych energii ${ }^{67}$, które wypełniając wszystkie wymiary immanentnego istnienia, stają się źródłem poznania Boga. Ta sama Chryzostomowa idea widoczna jest również $\mathrm{w}$ jego pneumatologii, kiedy medytując wydarzenie Pięćdziesiątnicy, akcentuje konieczność ciągłego i niekończącego się świętowania tej uroczystości przez chrześcijan ${ }^{68}$. Biblijne obrazy „ognia” i ,wody” często przekazują komunikat o obecności i działaniu Ducha Świętego, lecz nie są one ,imionami” istoty Boga. Dzięki tym słowom uświadamiamy sobie asystencję Boskiej energii Ducha Świętego ${ }^{69}$. Jan Chryzostom pokazuje, że choć istota rzeczy ściśle odnosi się do jej imienia, to jednak między istotą a słowami-imionami, czy też energiami, które ją charakteryzują, nie można postawić znaku równości. Istnienie jakiejś rzeczywistości oznacza się tym, lub innym pojęciem, oddającym jej sens. Co zaś tyczy się Boga, to nie ma takiego słowa, imienia czy obrazu, które adekwatnie by Go określało. Każde pojęcie, imię, czy obraz, dotyczący działania Boga, wyraża jedynie Jego „energetyczny” i „ekonomiczny” wymiar. Widząc istotę fragmentarycznie nie poznajemy „części” Bożej istoty, ponieważ Bóg jest Prosty i Jedyny. Doświadczamy natomiast różnych przejawów Jego mądrej ekonomii w świecie. Właśnie dlatego ,energetyczna" płaszczyzna poznania Boga umożliwia odkrycie hipostaz Trójcy Świętej. Jak wynika z teologicznej refleksji Chryzostoma, jednoznaczne uznanie tezy o przebiegającej jednocześnie ,istotowej” niepoznawalności i „energetycznej” poznawalności Boga, stanowi doktrynalny fundament dla zrozumienia i interpretacji teologii przebóstwienia.

Cyryl Aleksandryjski nie analizował tak głęboko zagadnienia Bożej transcendencji i immanencji przede wszystkim $\mathrm{z}$ tego powodu, iż nie było to wymuszone polemiką $\mathrm{z}$ herezjami, jak miało to miejsce w przypadku Jana Złotoustego. Niemniej jednak koncepcje tego ostatniego faktycznie pokrywa-

\footnotetext{
${ }^{65}$ Por. Papadopoulos, The Holy Trinity, nota 63.

${ }^{66}$ Por. tamże.

${ }^{67}$ Por. Joannes Chrysostomus, Expositiones in Ps. 44, 4, PG 55, 190.

${ }^{68}$ Por. Joannes Chrysostomus, In Acta Apostolorum hom. 4, 3; zob. Papadopoulos, The Holy

${ }^{69}$ Joannes Chrysostomus, In Joannem hom. 32, 1, PG 59, 183.
} Trinity, nota 63. 
ją się z opracowaniami Cyryla, który również dokonał rozróżnienia pomiędzy wewnętrznym bytowaniem Boga a Jego działaniem. Owo podobieństwo zawiera się $\mathrm{w}$ dwóch punktach: $1^{\circ}$ Bóg $\mathrm{w}$ swej istotowej naturze przewyższa wszystko i wszystkich. Wewnętrzne „bycie” Boga jest ponad i poza jakimkolwiek poznaniem, rozumowaniem, refleksją i dostępnością człowieka. Wszystko, co możemy z pewną dozą pewności stwierdzić o istocie Boga, ogranicza się do wiedzy o Jego działaniu w świecie - działaniu Ojca przez Syna w Duchu. $2^{\circ}$ Cyryl dla wyjaśnienia owego działania Boga stosuje dwa wyrażenia: moc i energia Boga, i nie dokonuje ich rozdziału. Boża energia i moc konstytuują świat, ożywiając i wypełniając wszystkie jego poziomy. Szczególnie dotyczy to tego rodzaju działania Ducha Świętego, które odpowiada za odnawianie życia.

Antynomiczny proces teologizowania obu tych autorów jest osią, która decyduje o właściwym ujęciu dwóch biegunów Bożego istnienia: transcendencji i immanencji. Propozycje Cyryla Aleksandryjskiego i Jana Złotoustego zaowocują tysiąc lat później stworzeniem teologicznej syntezy ich wkładu w rozwój interesującej nas tematyki, czego przykładem będzie twórczość św. Grzegorza Palamasa.

Z języka ukraińskiego przełożył ks. Lesław Łesyk

\author{
ANTIOCH AND ALEXANDRIA - WERE THEY ALWAYS \\ THEOLOGICALLY POLARIZED? THE PROBLEM OF GOD'S \\ TRANSCENDENCE AND IMMANENCE IN THE THEOLOGY \\ OF CYRIL OF ALEXANDRIA AND JOHN CHRYSOSTOM
}

(Summary)

Cyril of Alexandria did not treat the problem of God's transcendence and immanence as extensively and profoundly as did John Chrysostom, due to the fact that the question was not as relevant in Cyril's time as is was in the time of Chrysostom. However, the ideas of the latter are present in the writings of Cyril, who draws a distinction between the inner being of God and His work. This similarity can be traced in two main points. First, God in His essential nature surpasses everything. This inner life of God is above and beyond any knowledge and reach, any concept and reasoning. All that we know about the nature of God is that He acts in the world and this action is performed by the Father through the Son in the Spirit. Second, in order to outline God's action, Cyril uses the terms ,power” and „energy" indistinguishably. For both authors the method of antinomy is a primary system of coordinates in which they combine the two fundamentally opposite poles of God's being: the transcendent and the immanent. So, in this point the Oriental Theological Schools of Alexandria and Antioch are internally consonant. 